\title{
Social capital of urban settlement
}

\author{
Andarita Rolalisasi, Happy Santosa, Ispurwono Soemarno \\ Department of Architecture, Institut Teknologi Sepuluh Nopember (ITS), Surabaya, Indonesia
}

Email address:

andarita.rolalisasi@yahoo.com(Andarita Rolalisasi), happyratna@yahoo.com(Happy Santosa), isp4251@yahoo.com(Ispurwono Soemarno)

To cite this article:

Andarita Rolalisasi, Happy Santosa, Ispurwono Soemarno. Social Capital of Urban Settlement. Psychology and Behavioral Sciences. Vol. 2, No. 3, 2013, pp. 83-88. doi: 10.11648/j.pbs.20130203.11

\begin{abstract}
This is a literature review on social capital that hold together the community of settlement where people live in. It will discuss the spatial aspect of architectural behavior to conduct the theory framework. The methods used are qualitative analysis and literature review on the subjects of social capital, urban settlement, and kampung. Through a review of literature, the paper explores whether or not the spatial aspects of social capital of settlement available. The social capitals applied in many fields are economic, sociology, health, psychology, political science, and architecture. Due to many meanings of social capital in various fields, the important element of social capital is about social interaction among people to achieve their goals together. Kampung as urban settlement of Indonesia has unique characteristic of community due to their social living. Their relationship among them is very close. The social capital of urban settlement is shown in social interaction and social network of the resident at their daily lives. The communication is active, expressed in interaction related to gender and age structure. The social capital was developed from the trust and understanding in their relationship. The social capital of kampung helps them to live better.
\end{abstract}

Keywords: Spatial Aspect, Social Capital, City, Settlement, Kampung

\section{Introduction}

Social capital is an interesting topic in the diverse fields of knowledge as sociology, health, political sciences, economics education and architecture. Social capital concepts are already published in many journals and disciplines over the last decade. Reference [1] mentioned that this term is being widely ranged on policy, social, public health, community agendas and community initiatives. Social capital on most of these fields referred to something that holds society together and without which can be no economic growth or human well-being [2].

Urban settlement of Indonesia is having unique characteristic due to the process of how the settlement formed and community who live in. There are two kinds of housing provision that are formal and informal. Formal housing is provided by the housing developer, while informal housing are built by the owner. The settlement that built by the community themselves is called kampung. The community who live in the formal housing usually is having the same background, social and economic level, but many diverse in informal housing or kampung.

Reference [3] argued that social capital is intervened by economic capital existed at kampung. It showed in the kampung environmental quality improvement and community quality of life. Therefore, it [4] mentioned that kampung is an integral part of the city that as an organism live, growth, and live. City system transformation on physic, social, economic, and culture will change the social community system. The social capital is a part of the social community system.

The social capital and urban settlement such as kampung are both significant issues in building the behavior and environment in architecture. The urban settlement is having the social capital, will help the community gain a better living. As mentioned above, that social community system includes social capital is one of essential part of urban settlement. This paper explores the social capital concept from many points of view such as economics, sociology, psychology, and settlements and the interface between urban settlement and the resident of kampung, particularly in relation to spatial aspect of social capital.

The paper uses two methods. First, literature review of journals and publications that discussed social capital subjects in several fields; the urban settlements and spatial aspect of the social capital. It's to gain expansion how the subjects in previous researches such as [2], [3], [5]. Next is qualitative analysis methods that focus on interpretation 
and meaning [6]. This paper will focus on the interpreting and meaning of social capital of urban settlement.

\section{Social Capital}

Reference [7] stated that the social capital in many terms have been used since early 1920s in economic analysis. The sociologists stated that social capital exist as a basic concept of economy. At the same time, the economist said that the institution and social capital aspects always be present in economic analyses. He was looking for a social capital position in the composition theory. He began with classical economic theory about capital where the capital is a surplus of value and investment of commodities circulations. After that, he argued that social capital is another form of the new theory of capital.

Further [7] stated that social capital is a social network investment that recognized and acknowledged in the society structure included accessible to existing resources in a social network. An investment that recognized and acknowledged is a sense of solidarity in the community. This is in line with the opinion of scientists of sociology and politic [8], [9], [10], [11], who consistently has defined that the social capital is the interaction and networking among individuals in a variety of ways who has the resources to produce a profit. Moreover, [12], [13], mentioned that the social capital is a glue that holds the society.

There are many definitions and understandings of social capital depend on the perspective. The social capital in sociology term is the network, norm, and trust to achieve the goal that include arise actions and benefits. Social networks that are important element of social capital are developed by [2], [10], [11], [14]. They mentioned further that social capital is horizontal relationship among members of group that emphasized on the social network and limited on norm of group. Some people paid attention to the social structure and purpose of the group. They mentioned that social capital is human relationship which be affected by the quality, capacity, and social structure of the group to achieve their goal together. This understanding is in line with [8], [15], [16], [17].

Understanding the social capital in sociology depends on these fields. Reference [18] studied immigrant interaction at their new place. They found that social way of Mexican immigrant still exist post moved in US regarded social capital and their culture that influenced by economic aspect. In the other hand, social capital in term of health found that there was relation between social capital and the built environment including health. The link between physical environment, social capital and health support efforts that include intervention of infrastructure and policy measures will improve social capital [1], [19].

The social capital in psychology of health and place showed that there are links among social capital, the physic of environment, and health include psychology. Social capital has not been narrow as a warm fuzzy phenomenon, but also the link between physical environments, social capital, and health supports efforts to include infrastructure and policy measures in interventions to improve social capital [20].

Reference [3] argued that social capital is part of a sustainable development that will be growing, strong and rich when it used. It is contrary to the economic capital and environment capital that would be running out while used persistent. This social capital concept applied in settlement that depends on interaction process among members of group and the neighbourhood members. In the other hand, [21] mentioned that there is no significant relationship between (access to) social capital and residents' propensity to move, if controlling for socio-economic characteristics, housing and neighborhood perceptions and housing features. For this purpose, a social capital is operationalized as the benefit of cursory interactions, trusts, shared norms, and collective action among neighborhood members. It's in line with the sociologist perspective. The other study about built environment mentioned that resident who live in the environment that can be reached by walking have better social capital. It shown in more known the neighbors, involvement in politic, mutual trust and social engaging [22].

Due to many meaning of social capital in various field, the important element of social capital is about social interaction among people to achieve their goals together. The social capital relates with how the people in groups are making good communication among them in many ways. Besides that social capital of settlement shown in know each other the members of neighbourhood, mutual trust, and social engaging in settlement activities.

\section{Kampung}

Kampung is an urban settlement of low-income communities located in all functional parts of the city including in the most expensive area such as Central Business District, Government Centre, Shopping and Social Centre, etc [23]. Reference [25] stated that kampung is a settlement that unstructured, unorganized (see Fig 1), and have an informal economic activities (see Fig 2). Due to these condition, kampung in the most thought is an urban settlement that having limited infrastructure, unplanned and no economic networks.

However kampung is not as bad as thoughts the previous mentioned. References [23], [25] argued that kampung is neither slum nor squatter. Further [23] mentioned that it is a community development concept by community themselves. Kampung is not a merely physical aspect but it's a development process by community themselves due to cope with the housing access. Kampung is a unique urban settlement that provided $70 \%$ of the urban housing need for most middle low-income community. Kampung residents came from various ethnic, social and economic backgrounds. Before that, [25] already stated that kampung generally has a good community organization based on the 
vernacular values and cultures in Indonesia such as mutual aid system (gotong royong) that is indispensable to kampung life. Kampung is not only a residential area but also it is having function of production and consumption.

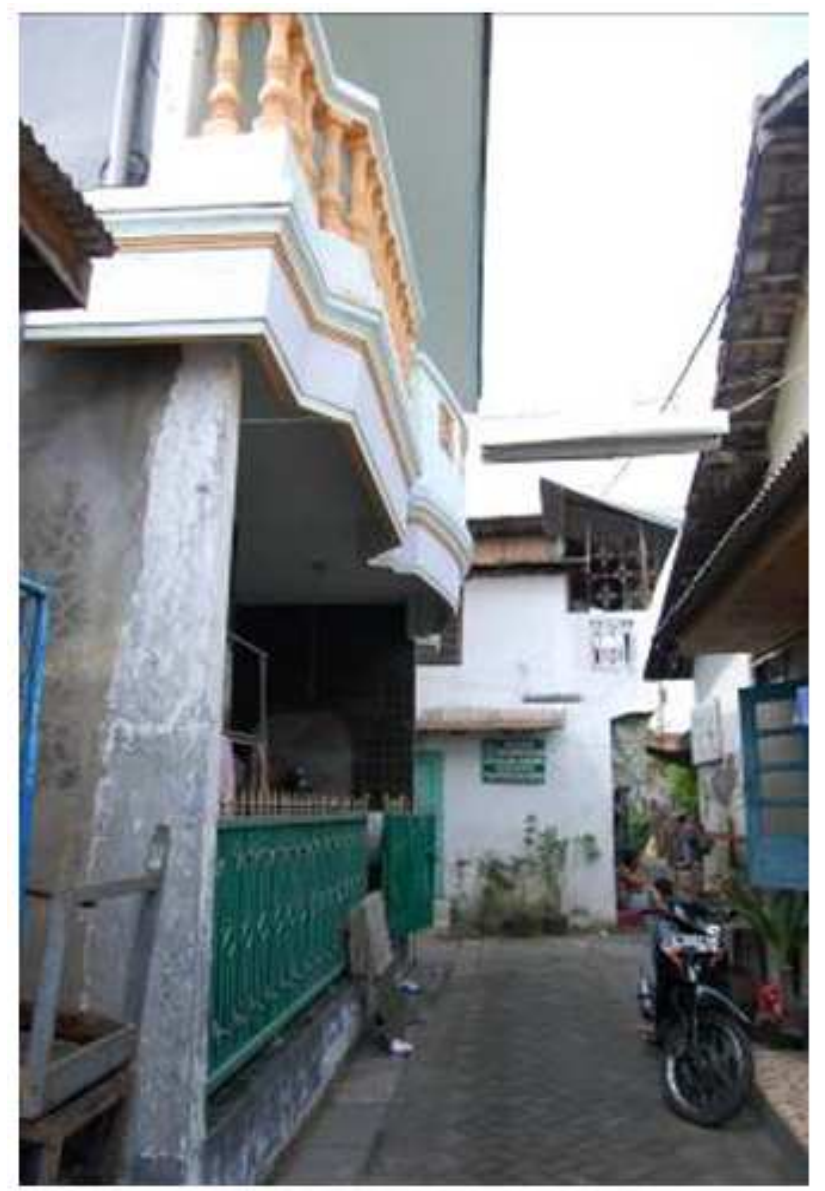

Figure 1. Kampung Tunjungan which located in Central Business District of Surabaya

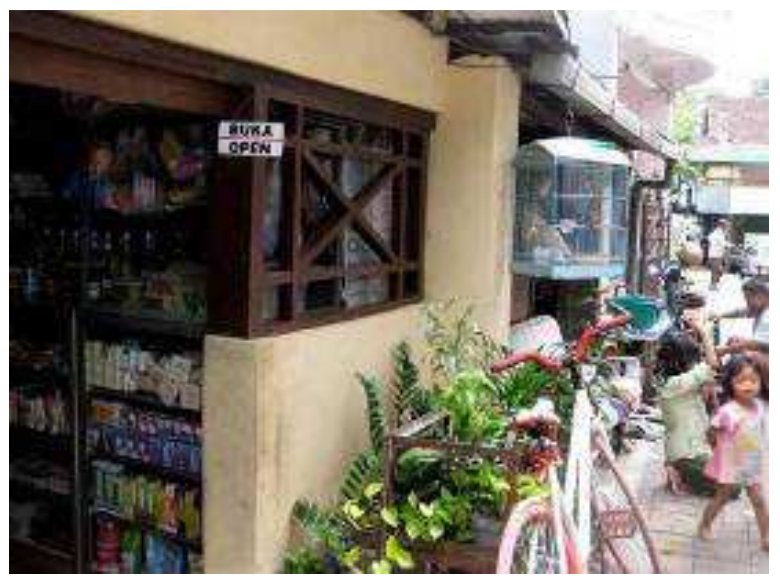

Figure 2. The informal economic activity of kampung, located in resident's house

Reference [24] mentioned that trading and commercial activities influenced the existence of kampung in the city. That's in line with [27] who stated that there was intense interaction of economic aspect between kampung and the city. Economic sub-system of kampung that called informal economic activities breaks down barriers between formal and informal aspect of economics to merge into the economic system of the city. Both opinions agreed that kampung is integral part of the city, which also applied to economic system. But they did not mention whether the relationship is linier or not.

Kampung is not about housing provision for low-income people, but they are having uniqueness and diversity of architecture that objectification on community of ideas, creativities, abilities, dreams, and pressure. There are many kampungs of Surabaya, which condition is not really bad. Surabaya had a lot of experiences in the kampung development programs that aimed to improve the quality of kampung conditions either physical or social-economic through community organization development and empowerment [28].

Kampung is also about the culture and heterogeneity. As [23] previous said that the resident of kampung came from various backgrounds and ethnics. Reference [25] mentioned that people tend to preserve the traditional way of life, which is also one of characteristics of the kampung. Kampung should be considered to be a settlement that has own vernacular values in Indonesia. Complexity of inhabitants is characteristic of kampung. It is sure that people from same region tends to live in the same area. But relationship between different groups is not always exclusive. It should be noticed that rich people support the life of the poor even in poorest kampung.

Kampung has various aspects. The first aspect is about housing provision for low-income people in inner city. Second is physical aspect, that people built the housing by themselves unplanned. The next is economic aspect that informal economic activities support the economics endurance of the city. The last aspect is social that about development process of community who live in the kampung, here resident help each other in their social life. The city gain benefits from the existence and all of various activities of the kampung.

\section{Social Capital of Urban Settlement}

There are three type of research on the potential relationship between social capital and physical environments like urban settlement, they are macro, meso and micro level. Research on macro level is studies of relationship between social capital and macro environmental trends (such as crime and stability). Meso level exploration on aspects of neighbourhood context or design. And micro level more investigation of the nexus between social capital and specific neighbourhood attributes and features [29].

Urban settlement consists of the neighbourhoods where community live in. The community referred to the web of interpersonal relationships of a person or a group, neighborhood refers to a geographic area. Neighborhood concepts were based on a perceived need to fulfill certain 
economics, social, and aesthetic goals. The physical components and the formal organizations of these can be designed from the outside but the communal organization has to come from within. The neighborhood reflects the social organizations that created by the community [30].

Previously, [1] mentioned that social capital associated with the number and perceives adequacy of destinations and the upkeep of physical neighbourhood environment. Reference [5] studied the social capital and spatial aspect on public space design. The collaboration between government and community will be effected to the social capital that passed through cultural, political, religious, and ethnic groups. This collaboration would build bridges the social capital of the community. He mentioned that social capital is a social interaction and social cohesion for all communities and the spatial aspect of social capital is a space as container for interaction and social cohesion for communities which included architectural design, location and the scheme of organization [5].

There was relation between social capital and feel of secure in the neighbourhood context. After adjustment for demographic factors, the built environment was found to have a significant but small effect on social capital and feelings of safety, particularly in relation to the number and perceived adequacy of destinations. A high level of neighborhood upkeep was associated with both higher social capital and feelings of safety [1].

Reference [25] stated that open space outside the house door is very significant aspect in kampung life. It is used for various communal activities that are cooking, playing, bathing, talking, etc (see Fig 3 and Fig 4). Their social capital in the neighborhood context runs into personal encounters in streets and squares, in playgrounds, and community centers [21]. Further [25] stated the open spaces function as a community spaces even its limited availability. Reducing open space more means the death of kampung.

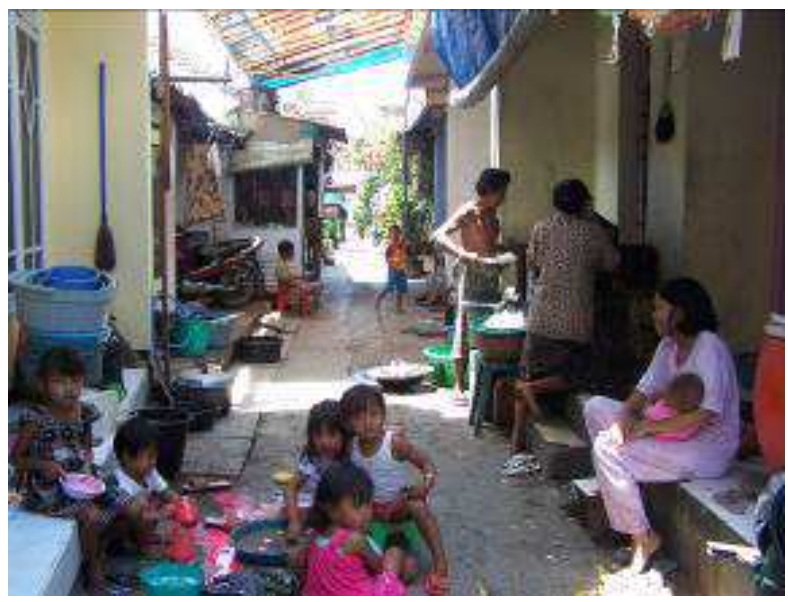

Figure 3. The various activities at the open space outside the door of houses in kampung

The physical aspect of kampung usually lack of space for communal activities. They need space for occasional moments and for their communal activities which circumstances give the best incentives for members of community to join in. They held the occasional moments such as neighbourhood gathering at street (see Fig 5) due to the lack of community spaces. The space also functions as playground for the children. There are some economic activities held at alley such as food seller and daily need seller [31].

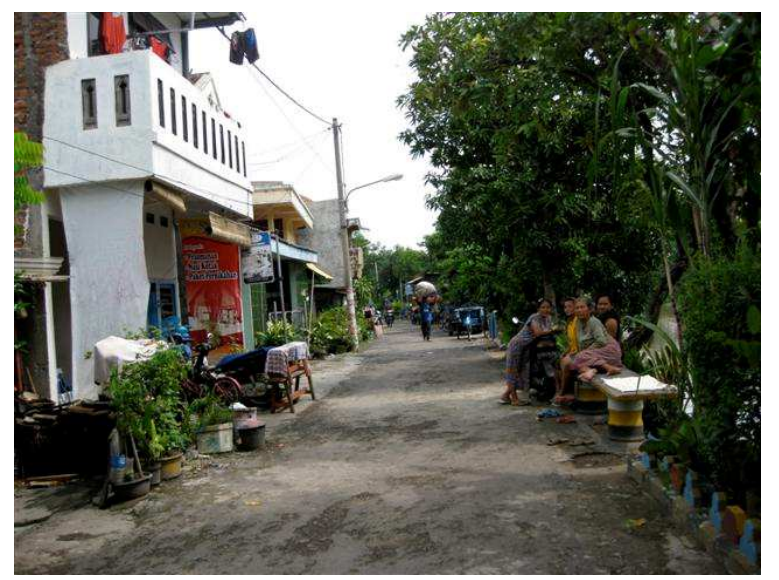

Figure 4. The street that part of riverbank and have extended function as communal space of urban settlement

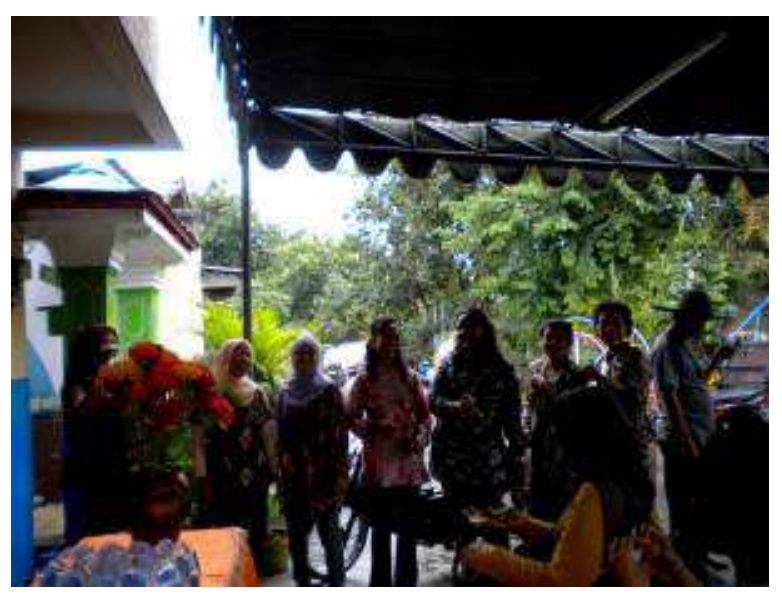

Figure 5. The neighbourhood gathering held at the street

As mentioned before that social capital is about relationship and many ways to interact among the people. The social capital of urban settlement resident is shown in their daily activities. The communication among them is active, expressed in interaction related to gender and age structure. Their social capital was developed from the trust and understanding of their relationship and contributes greatly in making the community stronger. It took a lot of time in producing a strong community, because the social capital cannot be created instantly and smoothly.

\section{Conclusion}

Urban settlement is not about physical aspect but also aspects of economic, social and culture of community and is part of the city system. Kampung is unique characteristic of urban settlement of Indonesia due to the way of community 
social living and development process of community to cope with the housing access.

Social capital is one of significant aspect of urban settlement to gain better living of community. For these purpose, social capital is referred to social interaction and social network of residents to achieve their goals together. The social capital of urban settlement is shown in the resident daily lives that were developed from the trust and understanding among them for example knew well their neighbors, held community gathering and activities together, etc.

The spatial aspect of social capital of settlement shown at the place where inhabitants making relationships among the members that it called community spaces. It's appeared in streets and squares, in playgrounds, community centers and other places where they are allowed making activities together.

\section{References}

[1] W. Lisa, T. Shannon, M. Bulsara, T. Pikora, G. Mccormack, and B Giles-Corti, The Anatomy of the Safe and Social Suburb: An Exploratory Study of Urban Form, Social Capital and Residents' Perception of Safety, Health and Place, 14, 2007, pp.15-31

[2] Christiaan Grootaert, Social Capital: The Missing Link?, Social Capital Initiative, Working Paper No. 3, The World Bank, Washington DC, 1998.

[3] Darrundono, Peran Modal Sosial dalam Proyek Pembangunan Kampung, Studi Kasus: Proyek Muhammad Husni Thamrin, Role of Social Capital in Urban Development Project, Case Study: Muhammad Husni Thamrin Project, Program Kajian Ilmu Lingkungan-Universitas Indonesia, Jakarta, 2007

[4] Bakti Setiawan, Kampung Kota dan Kota Kampung: Tantangan Perencanaan Kota di Indonesia, City Kampung and Kampung City: Challenging of Indonesia Urban Planning, Professor Inaugural Speech, Universitas Gajah Mada, 2010

[5] Gunnar HS Svendsen, Socio-spatial Planning in the Creation of Bridging Social Capital: the Importance of Multifunctional Centers for Intergroup Networks and Integration, in International Journal of Social Inquiry Volume 3 Number 2 2010 pp. 45-73, downloaded www.socialinquiry.org/articles/IJSI

-V3N22010\%20-\%20003.pdf, 12 October 2012, 2010.

[6] Linda Groat, David Wang, Architectural Research Methods, John Wiley \& Sons, Inc, 2002.

[7] Nan Lin, Building a Network Theory of Social Capital, Connections 22 (1), 1999, pp. 28-51.

[8] James S Coleman, Social Capital in the Creation of Human Capital, in American Journal of Sociology, 94, 1988, pp. S95-S120

[9] Pierre Bourdieu \& Loic Wacquant, Invitation to Reflexive Sociology. Chicago: University of Chicago Press, 1992

[10] Robert D Putnam, Robert Leonardi, Raffaella Nanetti,
Making Democracy Work, Princeton University Press, Princeton, NJ , 1993

[11] Robert D Putnam, The Prosperous Community-Social Capital and Public Life, American Prospect (13), 1993, pp. $35-42$

[12] A Altschuler, Somkin CP, \& Adler NE, Local Services and Amenities, Neighborhood Social Capital, and Health, in Social Science \& Medicine, 59, 2004, pp. 1219-1229

[13] William R Potapchuk, JP Crocker, \& WH Schechter, Building Community with Social Capital: Chits and Chums or Chats with Change, in National Civic Review, 86, 1997, pp. $129-13$

[14] Anthony Giddens, Sociology, 5th Edition, Polity Press, Malden, USA, ISBN 13:978-07456-3379-4, 2006

[15] M Olson, The Rise and Decline of Nations: Economic Growth, Stagflation, and Social Rigidities, Yale University Press, New Haven, 1982

[16] D North, Institutions, Instutional Change, and Economic Performance, Cambridge University Press, New York, 1990

[17] William G Flanagan, Urban Sociology, Image and Structures 1st Edition, ISBN 978-0-7425-6176-2, Rowman and Littlefield Publishers, United State, 2010

[18] Ruben Hernandez Leon, Victor Zuniga, Mexican Immigrant Communities in the South and Social capital, Center for Comparative Immigration Studies, UC San Diego, downloaded http://escholarship.org/uc/item/9r5749mm, 21 November 2012, 2002

[19] R Araya, F Dunstan, R Playle, H Thom., S Palmer, \& G Lewis, Perceptions of Social Capital and the Built Environment and Mental Health, Social Science \& Medicine, 62(12) , 2006, pp. 3072-3083

[20] Lisa Wood and Billie Giles-Corti, Is there a Place for Social Capital in the Psychology of Health and Place?, Journal of Environmental Psychology vol. 28, 2008, pp 154-163

[21] Reinout Kleinhans, Does Social Capital Residents' Propensity to Move from Restructured Neighbourhoods? Housing Studies, Vol. 24, No 5, 2009, pp 629-651

[22] Leyden, Kevin M, Social Capital and the Built Environment: The Importance of Walkable Neighborhoods, American Journal of Public Health Vol 93 No 9, pp. 1546 - 1551, 2003

[23] Johan Silas, The Kampungs of Surabaya, Surabaya Municipality, 1988

[24] Antony Sihombing, The Tranformation of Kampung Kota: Symbiosys Between Kampung and Kota; a Case Study from Jakarta,

www.housingauthority.gov.hk/hdw/ihc/pdf/phhkt.pdf, $\quad 1$ Februari 2013, 2004

[25] Shuji Funo, Dominant Issues of Three typical Kampungs in Surabaya and Consideration on Kmapung Housing System, Studies of Transitional Process of Kampungs and Evaluation of KIP, Symposium Proceeding Peran Perbaikan Kampung Dalam Pembangunan Kota di Indonesia, 1985

[26] Clifford Geertz, The Social History of an Indonesian Town, Greenwood Press Publisher, Westport, Connecticut, 1965

[27] Purwanita Setijanti, A Reflection on the Structure of the 
Modern Kampung, Jurnal Architecture and Environment Vol. 7 No.1 April 2008, 47-68, 2008

[28] Johan Silas, Wahyu Setyawan, Rita Ernawati, Mahesti Okitasari, Kampung Surabaya Menuju Abad 21, Kampung of Surabaya Towards 21st Century, Laboratorium Perumahan dan Permukiman ITS, Bappeko Surabaya, 2012

[29] Lisa Wood and Billie Giles-Corti, Is there a Place for Social Capital in the Psychology of Health and Place?, Journal of Environmental Psychology vol. 28 pp 154-163, 2008
[30] Jon Lang, Creating Architectural Theory, The Role of the Behavioral Sciences in Environmental design, van Nostrand Reinhold Company, ISBN 0-442-25981-6, 1987

[31] Andarita R, Happy S, Ispurwono S, Community Development Sustainability Through Social capital Potency in Supporting Smart Settlement along the Kalimas River, in Proceeding of Seminar in Innovative and Smart Settlement Enabling Local Economy, Department of Architecture ITS, 2012 